\title{
Late summer glacial meltwater contributions to Bull Lake Creek stream flow and water quality, Wind River Range, Wyoming, USA
}

Jeffrey VanLooy

University of North Dakota, jvanlooy@aero.UND.edu

Gregory S. Vandeberg

University of North Dakota, gregory.vandeberg@und.edu

\section{How does access to this work benefit you? Let us know!}

Follow this and additional works at: https://commons.und.edu/essp-fac

Part of the Earth Sciences Commons, and the Geography Commons

\section{Recommended Citation}

Jeffrey VanLooy and Gregory S. Vandeberg. "Late summer glacial meltwater contributions to Bull Lake Creek stream flow and water quality, Wind River Range, Wyoming, USA" (2019). Earth System Science and Policy Faculty Publications. 14.

https://commons.und.edu/essp-fac/14

This Article is brought to you for free and open access by the Department of Earth System Science and Policy at UND Scholarly Commons. It has been accepted for inclusion in Earth System Science and Policy Faculty Publications by an authorized administrator of UND Scholarly Commons. For more information, please contact und.commons@library.und.edu. 
Late summer glacial meltwater contributions to Bull Lake Creek stream flow and water quality, Wind River Range, Wyoming, USA

Jeffrey A. VanLooy ${ }^{\mathrm{a}^{*}}$ and Gregory S. Vandeberg ${ }^{\mathrm{b}}$

${ }^{a}$ Department of Earth System Science and Policy, University of North Dakota, 4149 University

Avenue, Stop 9011, Grand Forks, ND 58202-9011, USA

e-mail: jvanlooy@aero.und.edu

Phone: 701-777-4755

*corresponding author

${ }^{b}$ Department of Geography and GISc., University of North Dakota, 221 Centennial Drive, Stop

9020, Grand Forks, ND 58202-9020, USA

e-mail: gregory.vandeberg@und.edu

Phone: 701-777-4588 


\begin{abstract}
The Wind River Range in Wyoming contains more glacial ice than any other location within the Rocky Mountain States of Colorado, Idaho, Montana, and Wyoming of the United States. Bull Lake Creek watershed in the southeast portion of the range contains five major (0.6 to $1.5 \mathrm{~km}^{2}$ ) glaciers along with numerous smaller glaciers that contribute to the Wind River. Field measurements were made of discharge from Knife Point and Bull Lake glaciers to determine the contribution of glacial meltwater to the river system. Water samples were collected and analyzed for stable isotopes, major ions, nutrients and select trace elements. Meltwater from the glaciers contributed $13.9 \%$ to Bull Lake Creek streamflow during the sample period. Hydrogen and oxygen stable isotope analysis indicated as much as $80 \%$ of the discharge in upper Bull Lake Creek was attributed to glacial meltwater. All glaciers within the Bull Lake Creek watershed were estimated to be contributing 55.6 \% to stream flow for Bull Lake Creek for the late summer season. This study also found that nutrients $\left(\mathrm{NO}_{3}-\mathrm{NO}_{2}\right.$, Total P) from glacial meltwater can be a significant source of nutrient loading to Bull Lake Creek.
\end{abstract}

Key Words: glacial meltwater contribution, discharge measurements, stable isotope analysis, trace elements, nutrients, Wind River Range 


\section{Introduction}

Freshwater storage by glaciers is an important resource on a global, regional and local scale (Bennett and Glasser 2009; Schaner et al. 2012). However, most of the world’s mountain glaciers are retreating (Barry 2011; Beniston and Stoffel 2014; La Frenierre and Mark 2014), potentially impacting not only stream flow, but also ecosystems, tourism, agriculture, hydropower and other aspects of society (Beniston and Stoffel 2014; Carey et al. 2017; Huss et al. 2017). This is a particular concern for ecosystems and communities in arid and semi-arid regions of the world which rely on glacial melt as a supplemental water resource, such as in the western United States.

Surface water represents the majority of available water resources (76.5\%) in the intermountain west of the United States (Maupin et al. 2014). More than $70 \%$ of this surface water originates from the winter snow pack and a small portion from melting glaciers (Hall et al. 2012). Changes in the winter snow pack can have an impact on human activity as well as riparian ecosystems due to quantity and temperature changes of the meltwater (Amadio et al. 2005; Brown et al. 2007; Xu et al. 2009). Due to the great importance of the snow pack on riparian ecosystems and water resources, there is a clear need to be able to store this meltwater in reservoirs for use during the late summer season after which the snow pack has long since melted away. During years of low snowfall the lack of snow pack strains water resource use, as has recently been the case with droughts in the western U.S. which has led to declines in reservoir levels (Cook et al. 2007; Hall et al. 2015). However, if a supplemental source of water exists, such as a glacier, stream flow will likely be sustained despite the lack of remaining snow pack (Meier 1969; Mark et al. 2005; Stahl and Moore 2006). 
Glaciers are natural reservoirs which store water in both solid and liquid form as the near surface layers of firn and snow can act as an aquifer and the internal structure of a glacier often contains conduits and cavities which hold liquid water (Roethlisberger and Lang 1987, Fountain and Walder 1998). Liquid meltwater within the glacier can come from either glacial ice melt or surface snowmelt as the ice and snowmelt drains from the surface into moulins and internal ice cavities, at times becoming trapped or stored. Release of this stored water can be delayed until later in the summer season when glacier movement and melting cause internal changes that lead to new conduits for the meltwater to discharge to downstream flow (Jansson et al. 2003). This emphasizes the importance of the internal storage of the glacial system which is difficult to analyze yet necessary for precisely understanding the hydrology of a glacier (Fountain and Walder 1998, Jansson et al. 2003). Considering temperate glaciers are constantly contributing to stream flow during the melt season, there is a need to more closely and broadly monitor and understand their role in water resource contributions.

Glacier meltwater can also have an impact on the water quality of streams and coastal systems (Baron et al. 2009; Fegel et al. 2016; Zhang et al. 2017). Drainage within the glacier system can export nutrients and trace elements to local waterbodies (Hodson et al. 2008; Bhatia et al. 2013; Lawson et al. 2014; Jones and Parker 2015; Sun et al. 2017). Furthermore, reduced meltwater contributions to streamflow from glaciers and snow can negatively impact aquatic invertebrates and their habitats (Giersch et al. 2017). Species that rely on cold water streams, such as the meltwater stonefly (Lednia tumana), are expected to experience reduced habitat, due to changes in water temperature and quantity, and possible extinction as winter snowpack melts out earlier in the summer season and glaciers disappear (Giersch et al. 2017). 
The Wind River Range in west-central Wyoming contains the largest mass of glacial ice in the Rocky Mountains States of Colorado, Idaho, Montana, and Wyoming (Cheesbrough et al. 2009). The highest peaks of the range exceed $4,000 \mathrm{~m}$ with the majority of the glaciers existing above 3,500 $\mathrm{m}$. The range is bisected by the Continental Divide and is located within the Bridger and Fitzpatrick Wilderness Areas within the Bridger-Teton (to the west of the divide) and Shoshone (to the east of the divide) National Forests respectively. Due to the designation of the Wilderness Act (United States Congress 1964), travel by motorized vehicle is prohibited in this area, therefore access to research these glaciers is limited to horseback and on foot. This constraint leads to logistical and physical challenges that result in few field studies conducted on the Wind River Range glaciers (Marston et al. 1991; Naftz et al. 1991; Naftz and Smith 1993; Vandeberg and VanLooy 2016; VanLooy et al. 2013).

Comparatively, a large number of Wind River Range glacier studies have been conducted using remote sensing techniques (e.g. Cheesbrough et al. 2009; DeVisser and Fountain 2015; Maloof et al. 2014; Marks et al. 2015; Thompson et al. 2011). Most of these studies focus on the use of aerial imagery over many decades to determine changes in glacier area and relate these changes to recent climatic conditions. Several of these studies also incorporate area-volume scaling to calculate glacial volume changes over time (Maloof et al. 2014; DeVisser and Fountain 2015; Marks et al. 2015). These studies further attempt to estimate meltwater contribution to stream flow from these volume changes. However, there are issues with equivocating mass balance estimates directly to stream flow due to internal water storage (Hagg et al. 2004; Tangborn et al. 1971). Due to these methodological issues, it is difficult to accurately quantify how much a glacial system contributes to downstream flow without conducting field measurements directly at the glacier outlet stream. 
The primary objective of this study was to quantify the glacial meltwater contribution to the late summer stream flow of Bull Lake Creek and the Wind River, Wyoming. This research used a hybrid approach to estimate glacial meltwater contributions to streamflow by using the stream flow data collected in the field directly at the glacial sources in conjunction with the broad regional coverage of glacier areas determined from remote sensing data. As well, stable isotope analysis was conducted to measure the percentage of glacial discharge that consisted of glacial melt versus snowmelt. Glacial meltwater chemistry analysis was also conducted to determine meltwater quality.

\section{Materials and Methods}

\section{Study area}

The Bull Lake Creek watershed is located on the eastern side of the Continental Divide at the southern end of the highest portion of the Wind River Range (Figure 1). The watershed covers an area of approximately $554 \mathrm{~km}^{2}$ and as of September 2015 contains 23 glaciers covering $\sim 6.69 \mathrm{~km}^{2}$, or $1.2 \%$ of the watershed area (as determined from National Agriculture Imagery Program (NAIP) imagery). The glaciers are situated in the far northwestern portion of the watershed near the highest peaks in the range at elevations ranging from approximately 3,400 to 4,100 m. Meltwater flows into Bull Lake Creek which empties into the Wind River approximately $58 \mathrm{~km}$ downstream from the glaciers. Bull Lake Creek water passes through Bull Lake Reservoir which captures nearly all of the stream flow from the watershed before reaching the Wind River with a U.S. Geological Survey (USGS) gaging station situated just above the reservoir (station ID \#06224000) (USGS 2018) (Figure 1). Bedrock geology in the glacier areas near the mountain crests consists primarily of Precambrian gneisses, granites and ultra mafic 
crystalline rocks with sedimentary rocks present near where the tributaries meet the Wind River (Granger et al. 1971; Frost et al. 2006).

This study focuses on the meltwater from Knife Point and Bull Lake Glaciers (Figure 2). Knife Point Glacier is relatively low in elevation compared to most of the Wind River Range glaciers with elevations ranging from 3,400 to 3,800 $\mathrm{m}$. The glacier, which has an average slope of $21^{\circ}$, is situated in a cirque basin surrounded by extremely steep headwalls and has a north facing aspect. Bull Lake Glacier is situated to the northwest of Knife Point Glacier with a higher range of elevations between 3,600 and 3,900 $\mathrm{m}$. The slope of the glacier is relatively low at $15^{\circ}$, and with an east-northeast aspect it is much more exposed to the sun as the surrounding headwalls are not as high as around Knife Point Glacier. Field work was conducted between August 14 - 17, 2015 during which data were collected for stream flow, air temperature, and water chemistry at various locations around the study area.

\section{Stream discharge measurements}

Stream flow measurements were conducted at two locations: one approximately $100 \mathrm{~m}$ from the stream outlet location at Knife Point Glacier (KP-2), and a second below the confluence of the outlet streams for Knife Point and Bull Lake Glaciers (BL-3) (Figure 2). Measurements were not collected directly from the Bull Lake outlet stream (BL-2) as the terrain was too steep. Temporary gaging stations were installed at KP-2 and BL-3. The gaging stations consisted of vented Global Water Level Loggers (WL16) placed in perforated pvc stilling wells anchored to the stream bed. The water level loggers were set to record water depth at five minute intervals. Stream flow measurements were conducted at both gaging stations using a Hach MF Pro Meter with measurements along transects taken $0.3 \mathrm{~m}$ apart and at 40 second intervals (Turnipseed and 
Sauer 2010). A total of five measurements were conducted at KP-2 and included measurements during the diurnal high and low flows. At BL-3 only two stream flow measurements were conducted due to difficulty of crossing the stream and risky conditions for the person conducting the measurements, particularly during high flows. Stream flow measurements were used to determine the relationship between discharge and stage for the calculation of continuous discharge over the period of the field work. Discharge data along Bull Lake Creek were acquired from the three USGS gaging stations.

Glacial meltwater contribution was estimated for all non-gauged glacial outlet streams in the Bull Lake Creek watershed using an area-discharge ratio derived from the discharge measurements obtained at KP-2 and BL-3. Discharge measurements for this ratio were also included from a previous study at Continental Glacier in the Torrey Creek Watershed (Figure 1) on the northern end of the Wind River Range during 2012 (Vandeberg and VanLooy 2016). To justify the use of the 2012 Continental Glacier discharge data, climatic conditions along with stream discharge within the Wind River Range were analyzed for the two study dates (i.e. August $10-13$ in 2012, and August $14-17$ in 2015) to determine if the two study years were statistically similar. Mean daily temperature and precipitation data from three Snowpack Telemetry (SNOTEL) Network stations within the Wind River Range closest to the glaciers were analyzed: Gunsight Pass (ID\# 944; 2,993 m a.s.l.) approximately 11 km from Continental Glacier, Cold Spring (ID\# 405; 2,935 m a.s.l.) approximately 18 km from Continental Glacier, and Elkhart Park (ID\# 468; 2,865 m a.s.l.) approximately 15 km from Knife Point Glacier (Figure 1) (NRCS 2018). Snow water equivalence from the winters preceding 2012 and 2015 at these SNOTEL stations were also analyzed. Average daily discharge data from four USGS gaging stations (Bull Lake Creek above Bull Lake Reservoir (ID\# 06224000); Dinwoody Creek 
(ID\# 06221400); Pine Creek (ID\# 09196500); and Green River (ID\# 09188500)) (Figure 1) were analyzed for the same August study dates of 2012 and 2015 to determine if they were statistically similar. Statistical analysis for mean daily temperature and precipitation during the study dates for 2012 and 2015 was conducting using Mann-Whittney U tests. Statistical analysis of streamflow during the study dates for 2012 and 2015, and snow water equivalence for the winters preceding the 2012 and 2015 was conducted using a difference of means t-test.

Delineation and analysis of the glaciers were conducted using ArcGIS 10.3 (ESRI, Redlands, CA). Glaciers were digitized from National Agriculture Imagery Program (NAIP) aerial photographs from September 2015 with a spatial resolution of $1 \mathrm{~m}$ (USDA 2018). Estimation of discharge contribution of the non-gauged glacial meltwater outlet streams in Bull Lake Creek watershed in 2015 was calculated from the linear model of the average discharge for the three measurement sites (KP-2, BL-3, and Continental Glacier) versus glacier area.

\section{Sampling and laboratory analysis}

Air temperature was measured using Lascar EasyLog EL-USB-1 data loggers at three locations; the research camp (CT-1 at 3,401 m a.s.l.), and two locations on Knife Point Glacier (GT-1 at 3,466 m a.s.l., and GT-2 at 3,515 m a.s.l.) (Figure 2). On the glacier, ice axes were temporarily installed upright with the temperature data loggers attached by a short rope and hanging down from the end of the pick by about $6 \mathrm{~cm}$. At the research camp, the temperature data logger was installed along a guy wire half way between a tent and the ground with a distance of about $0.5 \mathrm{~m}$ between the ground and the data logger.

Water samples were collected at five locations across the study site: KP-1, KP-2, BL-2, BL-3, and SNO-2 (Figure 2). Specific conductivity, $\mathrm{pH}$ and temperature were measured in the field using an Oakton PCTestr 35 (Vernon Hills, Illinois, USA). The pH meter was calibrated 
daily to three standard references, and conductivity to one. Total dissolved solids (TDS) were calculated from specific conductance using a factor of 0.65 . Continuing calibration verifications were made during each round of readings. Sample locations were recorded using a Trimble GeoXH 6000 GPS receiver (Sunnyvale, California, USA) with differential correction ( $\pm 0.1 \mathrm{~m}$ horizontal accuracy).

Water samples were collected in 20 ml glass scintillation vials (3 per site) with poly caps for $\delta^{\mathbf{1 8}} \mathbf{O}$ and $\delta^{2} \mathbf{H}$ isotope analysis to determine the percentage of meltwater contribution from snow versus glacial meltwater. A duplicate sample was also collected at BL-3 (noted as BL-3D). A sixth sample (BL-1) was planned to be collected on Bull Lake Glacier, but due to difficulty of the terrain, it was not obtained. The samples were analyzed at the University of Wyoming Stable Isotope Facility (Laramie, Wyoming, USA) using Cavity Ring-Down spectroscopy (s.d. $=1$ \%oo for $\boldsymbol{\delta}^{\mathbf{2}} \mathbf{H}$, s.d. $=0.03 \mathbf{0} \%$ for $\left.\boldsymbol{\delta}^{\mathbf{1 8}} \mathbf{0}\right)$. Isotope values are presented as per mil $(\mathbf{\%} \mathbf{0 0})$ relative to Vienna standard mean ocean water (VSMOW) (Gat 2010). The results of the isotope ratios were compared relative to the local meteoric water line for western Wyoming, south central Montana and southeastern Idaho (Benjamin et al. 2004).

A two component isotope mixing model (Sklash and Farvolden 1979; Nolin et al. 2010; Klaus and McDonnell 2013) was used with glacier meltwater and snowmelt as the two end components:

$$
Q_{\text {glacier meltwater }}=\left(\frac{\delta^{18} O_{\text {stream }}-\delta^{18} O_{\text {snow }}}{\delta^{18} O_{\text {glacier meltwater }}-\delta^{18} O_{\text {snow }}}\right) * Q_{\text {stream }}
$$

where $Q$ = discharge, glacier meltwater is from Bull Lake or Knife Point Glacier discharge (BL2, KP-2), stream is discharge from Bull Lake Creek (BL-3) and snow is from snowmelt (SNO-2). The snow samples were collected at a similar elevation to the meltwater samples, so isotope ratio 
differences related to elevation should be minimal. Groundwater was not used as no springs were sampled in the study area.

Additional water samples were collected in precleaned and triple rinsed bottles (200-500 ml). Samples were kept cool on ice or snow, and preserved if necessary with acid $\left(\mathrm{HNO}_{3}\right.$ or $\mathrm{H}_{2} \mathrm{SO}_{4}$ ) depending on the analysis requirements. The water samples were transported on ice to Energy Laboratories (Billings, Montana, USA) for the following analyses: $\mathrm{NO}_{3}-\mathrm{NO}_{2}$ (method 353.2 by colorimetry); $\mathrm{SO}_{4}$ (method 300.0 by colorimetry), $\mathrm{P}$ total (method 365.1 by colorimetry); total $\mathrm{N}$; total Kjeldahl nitrogen (TKN) as $\mathrm{N}$ (method 351.2 by colorimetry); and 23 total recoverable elements (method 200 nitric-hydrochloric acid digestion followed by ICP-MS analysis using methods 200.7, 200.8 or 245.1 depending upon the element) (USEPA 1983). One field duplicate sample was collected at BL-3 and analyzed for quality assurance and control purposes. Analytical results were analyzed for descriptive statistics using IBM SPSS statistics 24 software (IBM New York, USA).

\section{Results and discussion}

\section{Glacial meltwater and stream discharge}

The discharge at KP-2 was measured directly from the glacial outlet with little to no influence from other water sources (i.e. large snow patches, lakes or ponds, etc.) with the stilling well located approximately $100 \mathrm{~m}$ from the terminus of Knife Point Glacier. Average glacial stream discharge at KP-2 as calculated from the stage measurements was $0.40 \mathrm{~m}^{3} \mathrm{~s}^{-1}$. The discharge measured at BL-3 occurred below the confluence of the Knife Point and Bull Lake outlet streams, and again had little influence from other water sources. Average glacial stream discharge at BL-3 as calculated from the stage measurements was $0.97 \mathrm{~m}^{3} \mathrm{~s}^{-1}$. The discharge 
from BL-2 $\left(0.57 \mathrm{~m}^{3} \mathrm{~s}^{-1}\right)$ representing meltwater from Bull Lake Glacier and the surrounding snow and ice patches was calculated as the difference in discharge from KP-2 and BL-3. A noticeable feature in the hydrograph (Figure 3) is a spike measuring over $2.5 \mathrm{~m}^{3} \mathrm{~s}^{-1}$ at BL-3 and over $1.0 \mathrm{~m}^{3} \mathrm{~s}^{-1}$ at KP-2 during the early morning hours of August 15. This spike is due to a precipitation event and was the only significant precipitation that occurred during the field observations. The mean August 2015 stream discharge at the USGS Bull Lake Creek station above the reservoir (ID \#06224000) was $7.0 \mathrm{~m}^{3} \mathrm{~s}^{-1}$.

Air temperature recorded at the field camp (CT-1) over the five day period fluctuated between $4^{\circ} \mathrm{C}$ and $35^{\circ} \mathrm{C}$, and between $0.5^{\circ} \mathrm{C}$ and $26^{\circ} \mathrm{C}$ on the glacier at GT-1 and GT-2 (Figure 3). Daytime temperatures are likely misleading as direct Sun radiation on the instrument may have warmed the sensor. This is likely the case as the highest recorded maximum temperature at any of the three SNOTEL sites (Elkhart Park which is approximately $550 \mathrm{~m}$ lower in elevation than CT-1) was $25.7^{\circ} \mathrm{C}$ (NRCS 2018). As well, the many dramatic temperature “spikes” noted on Figure 3 are a likely indication of rapid changes due to shifting cloud cover and Sun exposure on the sensor during daylight hours. Consequently, nighttime temperatures probably are more accurate due to the lack of the sun's influence. Air temperatures on the glacier were constantly above $0^{\circ} \mathrm{C}$ indicating that the glacier was continuously melting during the field study. This relatively warm minimum temperature may be related to observed warming minimum temperatures noted throughout the region since the year 2000 (Chang and Hansen, 2014).

The surface area of all of the Bull Lake Creek watershed glaciers determined by using the 2015 NAIP imagery was $6.69 \mathrm{~km}^{2}$. The five largest glaciers by area were Sacagawea $\left(1.50 \mathrm{~km}^{2}\right)$, Upper Fremont (1.18 km²), Bull Lake (1.17 km²), Helen $\left(0.89 \mathrm{~km}^{2}\right)$, and Knife Point $\left(0.63 \mathrm{~km}^{2}\right)$. Continental Glacier, $25 \mathrm{~km}$ to the North, had an area of $1.76 \mathrm{~km}^{2}$ with an average discharge of 
$1.01 \mathrm{~m}^{3} \mathrm{~s}^{-1}$ during the field work conducted August $10-13,2012$ (Vandeberg and VanLooy 2016). Statistical analysis was conducted for the justification of the use of 2012 Continental Glacier discharge data as a component of estimating the non-gauged glacial outlet streams for 2015 within the Bull Lake Creek watershed. Results of this analysis indicate that both 2012 and 2015 were statistically similar years in terms of temperature, snow water equivalence, and stream discharge within the Wind River Range during the dates of the field studies.

Average daily temperature for the three SNOTEL sites for the August study dates were $15.2^{\circ} \mathrm{C}$ in 2012 and $15.1^{\circ} \mathrm{C}$ in 2015 with a U Statistic of 67.5 and a critical value of 37. Average daily stream discharge at the four USGS gaging stations for the study dates were $6.5 \mathrm{~m}^{3}$ $\mathrm{s}^{-1}$ in 2012 and $6.6 \mathrm{~m}^{3} \mathrm{~s}^{-1}$ in 2015 with a p-value of 0.87 . Average daily stream discharge for only Bull Lake Creek above Bull Lake Reservoir (ID\# 06224000) was $7.3 \mathrm{~m}^{3} \mathrm{~s}^{-1}$ in 2012 and 7.8 $\mathrm{m}^{3} \mathrm{~s}^{-1}$ in 2015 with a $\mathrm{U}$ Statistic of 27 and a critical value of 17 . Average snow water equivalence for the three SNOTEL stations during the winters preceding 2012 and 2015 were 13.7 and $14.2 \mathrm{~cm}$ respectively and were statistically similar with a p-value of 0.63 . As well, the last day of snowmelt at any of the stations was June $2^{\text {nd }}$ for both 2012 and 2015. Finally, average precipitation from the three SNOTEL sites during the August study dates was $0.25 \mathrm{~cm}$ in 2012 and $0.18 \mathrm{~cm}$ in 2015, which are significantly different but negligible amounts. More importantly are the observed precipitation events that occurred at the study sites. Only one precipitation event occurred in 2015 and no precipitation events occurred in 2012. To determine the impact of the 2015 precipitation event on the average discharge measurements at KP-2 and BL-3, the discharge data represented by the "spike" in the hydrograph of Figure 3 were removed and discharge was recalculated with a result of $0.39 \mathrm{~m}^{3} \mathrm{~s}^{-1}$ at $\mathrm{KP}-2$, and $0.94 \mathrm{~m}^{3} \mathrm{~s}^{-1}$ at BL-3. This is a difference of $0.01 \mathrm{~m}^{3} \mathrm{~s}^{-1}$ at KP-2 and $0.03 \mathrm{~m}^{3} \mathrm{~s}^{-1}$ at BL-3, which is well within the uncertainty 
estimates at either site $\left( \pm 0.25 \mathrm{~m}^{3} \mathrm{~s}^{-1}\right.$ and $\pm 0.59 \mathrm{~m}^{3} \mathrm{~s}^{-1}$ respectively). Due to the statistical similarities in the climatic and streamflow conditions during the 2012 and 2015 field studies, the authors feel justified in using the 2012 Continental Glacier discharge data as a component in the linear model for estimating meltwater discharge of the non-gauged glacial outlet streams in Bull Lake Creek watershed in 2015.

The comparison of the average discharge for each glacier (i.e. Knife Point, Bull Lake, and Continental Glaciers) during the study period versus glacier area was plotted resulting in a linear model (Figure 4) which was then used to estimate the meltwater discharge for all nongauged Bull Lake Creek glacial outlet streams. The calculated estimations of meltwater from all the glaciers in the watershed indicated they contributed a total of $3.89 \mathrm{~m}^{3} \mathrm{~s}^{-1}$ to Bull Lake Creek which is $55.6 \%$ of the discharge measured at the Bull Lake Creek USGS gaging station above the reservoir (ID \#06224000) during the study period.

\section{Stable isotopes}

The analytical results for stable isotopes $\delta^{18} \mathrm{O}$ and $\delta{ }^{2} \mathrm{H}$ are shown in Table 2. We note that the total number of samples is limited, so the temporal and spatial variability of the supraglacial water (KP-1), snow (SNO-2), glacial meltwater (KP-2, BL-2) and stream water (BL-3) may not be fully characterized. All of the isotope results are depleted relative to the VSMOW standard, and fall adjacent and along the local meteoric water line of Benjamin et al. (2004) (Fig. 5). The snow samples in this study were most enriched in the stable isotopes measured relative to the other samples. Melting water in the snow pack can homogenize $\delta{ }^{2} \mathrm{H}$ and $\delta^{18} \mathrm{O}$ throughout the snow pack, and the isotopes can be enriched through evaporation (Gat 2010). We did not have any summer precipitation samples, but Benjamin et al. (2004) found 
$\delta{ }^{2} \mathrm{H}$ and $\delta^{18} \mathrm{O}$ isotopes in late season snow samples to be more depleted than summer precipitation. The stable isotopes $\delta{ }^{2} \mathrm{H}$ and $\delta^{18} \mathrm{O}$ are most depleted in the supraglacial samples collected on the surface of Knife Point Glacier (KP-1). This sample site is probably most indicative of the glacial ice composition because of the lack of melting snow nearby. The greater depletions of stable isotopes in the supraglacial samples relative to the VMSOW may be due to different atmospheric and/or elevation conditions when the ice was formed, or as it melted. The stable isotope depletions for the meltwater and stream samples (KP-2, BL-2 and BL-3) lie between the supraglacial meltwater and the snow samples, and likely represent a mix of melting glacial ice and snow. Our samples were collected in late summer and it is likely that the depletions, especially of $\delta^{18} 0$ would be variable from spring and summer to late summer (Cable et al. 2011, Williams et al. 2016, Carling et al. 2017).

The stable isotope signatures of $\delta{ }^{2} \mathrm{H}$ and $\delta^{18} 0$ show that the upper Bull Lake Creek late summer stream flow is dominated by glacial meltwater, because the isotope ratios for the meltwater (KP-1, KP-2, BL-2) and stream (BL-3) are similar versus the snow melt ratios (Fig. 5). The mean of glacial meltwater $\delta^{18} 0$ ratios from KP-2 and BL-3 was used as one of the components in the two part mixing model, along with the ratios from SNO-2 (Table 3). The isotope ratios show that seasonal snowmelt makes up about $20 \%$ of the late summer season flow to upper Bull Lake Creek, while glacial meltwater contributes about $80 \%$ of the late summer season flow for 2015 based on the time of sample collection. These results show how important late summer season glacial meltwater flow is to tributary streams in the Wind River Range (see also Cable et al. 2011, Vandeberg and VanLooy 2016).

\section{Water quality}


The geochemical signatures of the water samples in this study show differences between the water types, and allow for comparison with other glacial studies (Table 4). The snow has a much different geochemical signature than the supraglacial, glacial meltwater and stream samples. The snow samples had the highest concentrations of major ions, and total recoverable elements, often times an order of magnitude higher than the other samples. The crust of the snow was removed before collecting the snow sample, so the analytical results should not be biased by an enriched dust and debris layer on the snow surface. However, the snow sample was collected from only one location adjacent to Knife Point Glacier, so the elemental concentrations may not be totally representative of all the snow in the upper watershed. Total recoverable elements in the snow sample decreased in the following order: $\mathrm{Fe}>\mathrm{Al}>\mathrm{Ti}>\mathrm{Mn}>\mathrm{Zn}>\mathrm{Cu}>\mathrm{V}>\mathrm{Sr}>\mathrm{Pb}>\mathrm{Cr}>\mathrm{As}>$ Be. Since the element concentrations in the snow are so much higher than the streams or meltwater, an atmospheric source is likely (see Brahney et al. 2014, Carliing, et al. 2017). Carling et al. (2017) suggests that $\mathrm{Mn}, \mathrm{Hg}, \mathrm{Zn}, \mathrm{Cd}$, Co and $\mathrm{Pb}$ from supraglacial samples in the Teton Range, Wyoming are likely anthropogenic in origin from dust, aerosols or snowfall. They further identify gas production south and east of the Tetons, and agriculture in the Snake River Plain of Idaho as source areas for these elements.

A spatial component is seen in some of the field measured parameters, major ions and trace elements for the meltwater, supraglacial and stream samples. Specific conductance measurements increased with distance from the glaciers and were highest at BL-3 $\left(13.5 \mu \mathrm{S} \mathrm{cm}^{-1}\right)$ suggesting that the chemical weathering of geologic material increases dissolved solids (ions) in the discharge. Rock flour was also evident in meltwater from Knife Point and Bull Lake Glaciers, indicating a high suspended load. Baron et al. (2009) found very similar conductivity values in glacial meltwater in the Colorado Front Range, whereas in a much broader study, Fegel 
et al. (2016) found that specific conductance of glacier meltwater streams in the Rocky Mountains was mostly less than $50 \mu \mathrm{S} \mathrm{cm}^{-1}$ with similar temperatures and $\mathrm{pH}$ to this study. Carling et al. (2016) found conductivity to be highest in proglacial stream samples $\left(\sim 6 \mu \mathrm{Sm}^{-1}\right.$ $\left.12 \mu \mathrm{S} \mathrm{cm}^{-1}\right)$ followed by glacial meltwater $\left(\sim 2 \mu \mathrm{cm}^{-1}-3 \mu \mathrm{Sm}^{-1}\right)$, and supraglacial meltwater $\left(\sim 1 \mu \mathrm{S} \mathrm{cm} \mathrm{cm}^{-1}-2 \mu \mathrm{S} \mathrm{cm} \mathrm{cm}^{-1}\right)$ in the Teton Range, Wyoming. Major ions (Ca, Mg, K, Si), excluding the snow sample, are most elevated at BL-2 with Si the most abundant of the ions (Table 4). Trace elements of $\mathrm{Al}, \mathrm{Cu}, \mathrm{Fe}, \mathrm{Pb}, \mathrm{Mn}, \mathrm{Sr}, \mathrm{Ti}$ and $\mathrm{Zn}$ show a similar trend in decreasing in a downstream direction from the glacial meltwater locations (KP-2, BL-2) to the Bull Lake stream sample (BL-3). The supraglacial sample (KP-1) had trace element concentrations most similar to BL-3. The major elements of Fe, Mg, Ca and Ti were present (7 \% to $<0.002 \%$ ) in migmatite and breccia bedrock samples collected in the study area, with Fe being the most abundant (Granger et al. 1971). Trace elements such as Mn, B, Ba, Be, Co, Cr, Cu, Ni, Pb and Sr were detected in sand samples collected from Bull Lake Creek (Granger et al. 1971). These bedrock and sand particle chemistries support a geologic source for some of these elements in the KP-2 and BL-2 samples. Because major ions and total recoverable elements were most abundant in the snowmelt sample (SNO-2), snowmelt is also a likely source for these elements and ions in the glacial meltwater. Carling et al. (2016) found higher concentrations of Mn, Hg, Zn, Cd, Co and $\mathrm{Pb}$ in supraglacial meltwater relative to downstream in the Teton Range, Wyoming, and attributed the elements to anthropogenic sources.

Total nitrogen and phosphorus were most abundant in snow, whereas nitrate-nitrite was most abundant in water from BL-3 (Table 4). Nitrate-nitrite increases in a downstream direction with KP-1 having the lowest concentration, followed by Knife Point and Bull Lake glacial meltwater, and the Bull Lake stream sample (BL-3). Nitrate-nitrite are the mineral components 
of nitrogen, and bioavailable. Nitrogen was most prevalent as TKN (organic nitrogen and ammonia) and total nitrogen in the snow sample, but was not detected in the other samples, probably because of the high detection level $\left(0.5 \mathrm{mg} \mathrm{l}^{-1}\right)$ for the methods used. Total phosphorus was an order of magnitude higher in the snow versus the other water samples.

Many studies have examined the nutrient contributions of glacier systems to watershed (e.g. Baron et al. 2009; Saros et al. 2010; Bhatia et al. 2013; Brahney et al. 2014; Lawson et al. 2014; Fegel et al. 2016; Zhang et al. 2017). Baron et al. (2009) documented a 30.9\% increase of nitrate concentrations $\left(0.40 \mathrm{mg} \mathrm{l}^{-1}-0.52 \mathrm{mg} \mathrm{l}^{-1}\right)$ from the Sky Pond inlet flow from the Taylor Rock Glacier in the Colorado Front Range, and noted that the melting glaciers in the system allow for more nitrogen to be flushed into the system. These nitrate concentrations are higher overall than the concentrations found in this study. Saros et al. (2010) found higher nitrate concentrations from glacier fed systems $\left(0.114 \mathrm{mg} \mathrm{l}^{-1}\right)$ versus snow-fed lakes $\left(0.004 \mathrm{mg} \mathrm{l}^{-1}\right)$ in Montana. Possible mechanisms for these higher nitrate concentrations may be associated with evaporative concentration, less biological interaction to reduce the nitrates, and possible nitrification of ammonia in snow and ice melt (Saros et al. 2010). Branhney et al. (2014) found total phosphorus concentrations in alpine lakes in the southwestern part of the Wind River Range from approximately $0.005 \mathrm{mg} \mathrm{l}^{-1}$ to $0.013 \mathrm{mg} \mathrm{l}^{-1}$, and identified atmospheric dust as a contributor to water nutrients. Data from this study and Vandeberg and VanLooy (2016) regarding glacial meltwater in the Wind River Range, show that glaciers can release a fair amount of nutrients to local streams (Figure 6). Late summer nitrate-nitrite loading from Bull Lake (BL-2) and Knife Point (KP-2) Glaciers can account for $79.5 \%$ of the loading found in Bull Lake Creek (BL-3), while $90 \%$ of the $\mathrm{NO}_{3}-\mathrm{NO}_{2}$ loading in the northern Wind River tributary of Torrey Creek (TCR-1, Figure 6) can be accounted for with discharge from Continental Glacier (CG-1). 
The Bull Lake and Knife Point Glacier meltwater can account for almost $50 \%$ of the late summer total P loading to Bull Lake Creek (BL-3). Discharge from Continental Glacier (CG-1) accounts for about $26 \%$ of $\mathrm{P}$ loading to Torrey Creek. Phosphorus is present in many sources such as the mineral apatite, fertilizers, diesel fuel emissions and biomass burning (Boyd 2015; Pearson et al. 2015). Phosphorus-rich bedrock is present near the confluence of the tributaries and the Wind River, but not within the upper study area (Granger et al. 1971), so atmospheric deposition is the most likely source for the total $\mathrm{P}$ within the glacier meltwater.

\section{Conclusions}

Measured discharge from Knife Point Glacier within the Bull Lake Creek watershed averaged $0.40 \mathrm{~m}^{3} \mathrm{~s}^{-1}$ with a range of 0.07 to $1.24 \mathrm{~m}^{3} \mathrm{~s}^{-1}$ over a five day period in mid-August 2015. This discharge corresponds to a $5.7 \%$ contribution to Bull Lake Creek during this same time period. Measured discharge below the confluence of the Knife Point and Bull Lake Glacier outlet streams was $0.97 \mathrm{~m}^{3} \mathrm{~s}^{-1}$ with a range of 0.23 to $2.57 \mathrm{~m}^{3} \mathrm{~s}^{-1}$, which equates to a contribution of $8.1 \%$ to Bull Lake Creek. The estimated discharge of all Bull Lake Creek watershed glaciers based on the area-discharge ratio is $3.89 \mathrm{~m}^{3} \mathrm{~s}^{-1}$ which contributes approximately $55.6 \%$ to the Bull Lake Creek stream flow. These results support the idea that watersheds with small glacier cover (1.2 \% for the Bull Lake Creek watershed) can contribute significantly to stream flow in the late summer season during years of low snowfall (Stahl and Moore, 2006). It should be noted that due to the relatively high temperatures during the field work $\left(15.1^{\circ} \mathrm{C}\right)$ as compared to the August monthly average temperatures $\left(12.7^{\circ} \mathrm{C}\right)$ as calculated from the three SNOTEL stations, the discharge of the glaciers may be higher than average for this particular month. However, these results may be more representative of years like 2012 which experienced high 
average temperatures $\left(14.7^{\circ} \mathrm{C}\right)$ throughout August, which shows the significance of glacier discharge in the Bull Lake Creek watershed during hot, dry years when glacial meltwater is needed to supplement water resources.

These results are compared with Cable et al. (2011) who, while in a different watershed (Dinwoody Creek) just to the north of Bull Lake Creek watershed, found similar results of glacial contributions to stream flow using stable isotope analysis. In Dinwoody Creek watershed during a year with reduced snowpack (2007) glacial meltwater contributions were calculated to be as much as $70 \%$ of the stream flow from July to mid-October (Cable et al. 2011). As well, stable isotope and stream flow analysis from a third watershed (Torrey Creek) indicated $82 \%$ glacial meltwater contributions to Torrey Creek and $10 \%$ to the Wind River during August (Vandeberg and VanLooy 2016).

This study found that nutrients from glacial meltwater can be a significant source of total nutrient loading in Bull Lake Creek. Snowmelt had the highest concentrations of major ions (Ca, $\mathrm{Mg}, \mathrm{K}, \mathrm{Si}, \mathrm{Na}, \mathrm{SO}_{4}$, and TDS) followed by Bull Lake Glacier and Knife Point Glacier meltwater, and Bull Lake Creek water. Total recoverable elements were most elevated in the snow sample (SNO-2) and decreased in the following order: $\mathrm{Fe}>\mathrm{Al}>\mathrm{Ti}>\mathrm{Mn}>\mathrm{Zn}>\mathrm{Cu}>\mathrm{V}>\mathrm{Sr}>\mathrm{Pb}>\mathrm{Cr}$ $>$ As > Be. Lower concentrations of total recoverable elements were present in Bull Lake Glacier and Knife Point Glacier meltwater, followed by Bull Lake Creek water. The geochemistry of the glacier meltwater represents a likely interaction between elements from atmospheric deposition (snow) and glacier interaction with the surrounding bedrock. These elements are introduced into Bull Lake Creek, and can increase the total element loading to the stream system. 
The results of this study along with the findings of other similar studies indicate that the glaciers of the Wind River Range, Wyoming are substantially contributing to downstream flow, particularly during the late summer season of dry years. This should be of great concern to water resource managers in the surrounding area as the disappearance of these glaciers will likely lead to significant reductions in water flow and changes in both the riparian ecosystems and the economic activities immediately downstream. The results of this study emphasize the need for more discharge field measurements and improved accuracy in the quantification of glacial meltwater contributions to major watersheds. As well, new and better methods for validating the accuracy of reported glacial melt water contributions in the literature is needed. This is particularly necessary in arid regions such as the western United States where accurate reporting of all water resources is critical for proper water management, especially in light of increased water scarcity due to changing climatic conditions.

\section{Acknowledgements}

Investigations were supported by funding from the Greater Yellowstone Coordinating Committee and Shoshone National Forest (agreement number: 15-CS-11021400-008), and in part from the Vice President for Research and Economic Development, University of North Dakota. We would like to thank the Shoshone and Bridger-Teton National Forests for their assistance in the study, particularly Karri Cary of Shoshone National Forest for her guidance in obtaining funds for this study. We would like to thank Spencer Wheeling, Emma Lord, Benjamin York, and Jacob Nordberg for their assistance in the field. Finally, we would like to 
thank Derrick Sellergren and Blucher Creek Outfitters for their support and assistance in traveling to the field site.

\section{Declaration of interest}

No potential conflict of interest was reported by the authors. 


\section{References}

Amadio, C. J., Hubert, W. A., Johnson, K., Oberlie, D. \& Dufek, D. (2005). Factors affecting the occurrence of saugers in small, high-elevation rivers near the western edge of the species' natural distribution. Transactions of the American Fisheries Society, 134(1), 160-171. doi:10.1577/FT03-225.1.

Baron, J. S., Schmidt, T. M. \& Hartman, M. D. (2009). Climate-induced changes in high elevation stream nitrate dynamics. Global Change Biol., 15(7), 1777-1789.

Barry, R. G. (2011). The cryosphere-past, present,and future: a review of the frozen water resources of the world. Polar Geography, 34(4), 219-227.

Beniston, M. \& Stoffel, M. (2014). Assessing the impacts of climatic change on mountain water resources. Science of the Total Environment, 493, 1129-1137.

doi:10.1016/j.scitotenv.2013.11.122.

Benjamin, L., Knobel, L. L., Hall, L. F., Cecil, L. D. \& Green, J. R. (2004). Development of a local meteoric water line for southeastern Idaho, western Wyoming, and south-cental Montana (Report No. 2004-5126). Idaho Falls, Idaho: U.S. Geological Survey.

Bennett, M. R. \& Glasser, N. F. (2009). Glacial Geology Ice Sheets and Landforms. (Anonymous Trans.). (Second ed.). West Sussex, United Kingdom: Wiley-Blackwell.

Bhatia, M. P., Das, S. B., Xu, L., Charette, M. A., Wadham, J. L. \& Kujawinski, E. B. (2013). Organic carbon export from the Greenland ice sheet. Geochimica et Cosmochimica Acta, 109, 329-344. doi:10.1016/j.gca.2013.02.006.

Boyd, C. E. (2015). Water Quality An Introduction. (Anonymous Trans.). (2 ed.). New York: Springer International.

Brahney, J., Ballantyne, A. P., Kociolek, P., Spaulding, S., Otu, M., Porwoll, T. \& Neff, J. C. (2014). Dust mediated transfer of phosphorus to alpine lake ecosystems of the Wind River Range, Wyoming, USA. Biogeochemistry, 120, 259-278.

Brown, L. E., Hannah, D. M. \& Milner, A. M. (2007). Vulnerability of alpine stream biodiversity to shrinking glaciers and snowpacks. Global Change Biology, 13(5), 958-966. doi:10.1111/j.1365-2486.2007.01341.x.

Cable, J., Ogle, K. \& Williams, D. (2011). Contribution of glacier meltwater to streamflow in the Wind River Range, Wyoming, inferred via a Bayesian mixing model applied to isotopic measurements. Hydrological Processes, 25(14), 2228-2236. doi:10.1002/hyp.7982.

Carey, M., Molden, O. C., Rasmussen, M. B., Jackson, M., Nolin, A. W. \& Mark, B. G. (2017). Impacts of Glacier Recession and Declining Meltwater on Mountain Societies. Annals of the American Association of Geographers, 107(2), 350-359. doi:10.1080/24694452.2016.1243039. 
Carling, G. T., Rupper, S. B., Fernandez, D. P., Tingey, D. G. \& Harrison, C. B. (2017). Effect of Atmospheric Deposition and Weathering on Trace Element Concentrations in Glacial Meltwater at Grand Teton National Park, Wyoming, U.S.A. Arctic, Antarctic, and Alpine Research, 49(3), 427-440. doi:10.1657/AAAR0016.071.

Chang, T., and Hansen, A. (2014). Climate Change Brief: Greater Yellowstone Ecosystem. (Great Northern Landscape Conservation Cooperative: Landscape Climate Change Vulnerability Project). Montana State University.

Cheesbrough, K., Edmunds, J., Tootle, G., Kerr, G. \& Pochop, L. O. (2009). Estimated Wind River Range (Wyoming, USA) glacier melt water contributions to agriculture. Remote Sensing, 1, 818-828. doi:10.3390/rs1040818.

Cook, E. R., Seager, R., Cane, M. A. \& Stahle, D. W. (2007). North American drought: Reconstructions, causes, and consequences. Earth-Science Reviews, 81(1-2), 93-134. doi:10.1016/j.earscirev.2006.12.002.

DeVisser, M. H. \& Fountain, A. G. (2015). A century of glacier change in the Wind River Range, WY. Geomorphology, 232(0), 103-116. doi://dx.doi.org/10.1016/j.geomorph.2014.10.017.

Fegel, T. S., Baron, J. S., Fountain, A. G., Johnson, G. F. \& Hall, E. K. (2016). The differing biogeochemical and microbial signatures of glaciers and rock glaciers. J.Geophys.Res.G Biogeosci., 121(3), 919-932. doi:10.1002/2015JG003236.

Fountain, A.G. and Walder, J.S. (1998). Water flow through temperate glaciers. Reviews of Geophysics, 36(3), 299-328.

Frost, C. D., Fruchey, B. L., Chamberlain, K. R. \& Frost, B. R. (2006). Archean crustal growth by lateral accretion of juvenile supracrustal belts in the south-central Wyoming Province. Canadian Journal of Earth Sciences, 43(10), 1533-1555. doi:10.1139/e06-092.

Gat, J.R. (2010). Isotope Hydrology, London: Imperial College Press.

Giersch, J. J., Hotaling, S., Kovach, R. P., Jones, L. A. \& Muhlfeld, C. C. (2017). Climateinduced glacier and snow loss imperils alpine stream insects. Global Change Biology, 23(7), 2577-2589. doi:10.1111/gcb.13565.

Granger, H. C., McKay, E. J., Mattick, R. E., Patten, L. L. \& McIlroy, P. (1971). Mineral resources of the Glacier Primitive Area, Wyoming. U.S. Geological Survey Bulletin, 1319-F, 1112.

Hagg, W. J., Braun, L. N., Uvarov, V. N. \& Makarevich, K. G. (2004). A comparison of three methods of mass-balance determination in the Tuyuksu glacier region, Tien Shan, Central Asia. Journal of Glaciology, 50(171), 505-510. 
Hall, D. K., Crawford, C. J., DiGirolamo, N. E., Riggs, G. A. \& Foster, J. L. (2015). Detection of earlier snowmelt in the Wind River Range, Wyoming, using Landsat imagery, 1972-2013.

Remote Sensing of Environment, 162, 45-54. doi:10.1016/j.rse.2015.01.032.

Hall, D. K., Foster, J. L., DiGirolamo, N. E. \& Riggs, G. A. (2012). Snow cover, snowmelt timing and stream power in the Wind River Range, Wyoming. Geomorphology, 137(1), 87-93. doi:10.1016/j.geomorph.2010.11.011.

Hodson, A., Anesio, A. M., Tranter, M., Fountain, A., Osborn, M., Priscu, J....Sattler, B. (2008). Glacial ecosystems. Ecological Monographs, 78(1), 41-67.

Huss, M., Bookhagen, B., Huggel, C., Jacobsen, D., Bradley, R. S., Clague, J. J....Winder, M. (2017). Toward mountains without permanent snow and ice. Earth's Future, doi:10.1002/2016EF000514.

Jansson, P., Hock, R. \& Schneider, T. (2003). The concept of glacier storage: A review. Journal of Hydrology, 282(1-4), 116-129.

Jones, N. \& Parker, C. (2015). Water quality in two Icelandic rivers: The influence of impoundment, agriculture, glaciation and permafrost. Hydrological Research, 46(3), 429-445. doi:10.2166/nh.2014.268.

Klaus, J. \& McDonnell, J. J. (2013). Hydrograph separation using stable isotopes: Review and evaluation. Journal of Hydrology, 505, 47-64. doi:10.1016/j.jhydrol.2013.09.006.

La Frenierre, J. \& Mark, B. G. (2014). A review of methods for estimating the contribution of glacial meltwater to total watershed discharge. Progress in Physical Geography, 38, 173-200. doi:10.1177/0309133313516161.

Lawson, E. C., Bhatia, M. P., Wadham, J. L. \& Kujawinski, E. B. (2014). Continuous summer export of nitrogen-rich organic matter from the greenland ice sheet inferred by ultrahigh resolution mass spectrometry. Environmental Science Technology, 48(24), 14248-14257. doi:10.1021/es501732h.

Maloof, A., Piburn, J., Tootle, G. \& Kerr, G. (2014). Recent Alpine Glacier Variability: Wind River Range, Wyoming, USA. Geosciences, 4, 191-201. doi:10.3390/geosciences4030191.

Mark, B. G., McKenzie, J. M. \& Gómez, J. (2005). Hydrochemical evaluation of changing glacier meltwater contribution to stream discharge: Callejon de Huaylas, Peru. Hydrological Sciences Journal, 50(6), 975-988. doi:10.1623/hysj.2005.50.6.975.

Marks, J., Piburn, J., Tootle, G., Kerr, G. \& Oubeidillah, A. (2015). Estimates of glacier mass loss and contribution to streamflow in the Wind River Range in Wyoming: Case study. Journal of Hydrological Engineering, 20(8). doi:10.1061/(ASCE)HE.1943-5584.0001050. 
Marston, R. A., Pochop, L. O., Kerr, G. L., Varuska, M. J. \& Veryzer, D. J. (1991). Recent glacier changes in the Wind River Range, Wyoming. Physical Geography, 12(2), 115-123.

Maupin, M. A., Kenny, J. F., Hutson, S. S., Lovelace, J. K., Barber, N. L. \& Linsey, K. S. (2014). Estimated use of water in the United States in 2010. U.S. Geological Survey Circular, 1405.

Meier, M. F. (1969). Glaciers and water supply. Journal of the American Water Works Association, 61(1), 8-12.

Naftz, D. L., Rice, J. A. \& Ranville, J. R. (1991). Glacial ice composition: a potential long-term record of the chemistry of atmospheric deposition, Wind River Range, Wyoming. Water Resources Research, 27(6), 1231-1238.

Naftz, D. L. \& Smith, M. (1993). Ice thickness, ablation, and other glaciological measurements on Upper Fremont Glacier, Wyoming. Physical Geography, 14(4), 404-414.

doi:10.1080/02723646.1993.10642488.

Nolin, A. W., Phillippe, J., Jefferson, A. \& Lewis, S. L. (2010). Present-day and future contributions of glacier runoff to summertime flows in a Pacific Northwest watershed: Implications for water resources. Water Resources Research, 46(12), 1-14. doi:10.1029/2009WR008968.

NRCS. (2018). Natural Resource Conservation Service: National Water and Climate Center. United States Department of Agriculture: https://www.wcc.nrcs.usda.gov/webmap [Last Accessed: 10-25-2018].

Pearson, C., Schumer, R., Trustman, B. D., Rittger, K., Johnson, D. W. \& Obrist, D. (2015). Nutrient and mercury deposition and storage in an alpine snowpack of the Sierra Nevada, USA. Biogeosciences, 12(12), 3665-3680. doi:10.5194/bg-12-3665-2015.

Roethlisberger, H. \& Lang, H. (1987). Glacial hydrology. In A. M. Gurnell \& M. J. Clark (Eds.). (Anonymous Trans.). (, pp. 207-284). New York: Wiley.

Saros, J. E., Rose, K. C., Clow, D. W., Stephens, V. C., Nurse, A. B., Arnett, H. A....Wolfe, A. P. (2010). Melting Alpine Glaciers Enrich High-Elevation Lakes with Reactive Nitrogen. Environ.Sci.Technol., 44(13), 4891-4896. doi:10.1021/es100147j.

Schaner, N., Voisin, N., Nijssen, B. \& Lettenmaier, D. P. (2012). The contribution of glacier melt to streamflow. Environmental Research Letters, 7(3). doi:10.1088/1748-9326/7/3/034029.

Sklash, M. G. \& Farvolden, R. N. (1979). The role of groundwater in storm runoff. Journal of Hydrology, 43(1-4), 45-65.

Stahl, K. \& Moore, R. D. (2006). Influence of watershed glacier coverage on summer streamflow in British Columbia, Canada. Water Resources Research, 42(6). doi:10.1029/2006WR005022. 
Sun, X., Wang, K., Kang, S., Guo, J., Zhang, G., Huang, J....Zhang, Q. (2017). The role of melting alpine glaciers in mercury export and transport: An intensive sampling campaign in the Qugaqie Basin, inland Tibetan Plateau. Environmental Pollution, 220, 936-945.

doi:10.1016/j.envpol.2016.10.079.

Tangborn, W. V., Krimmel, R. M. \& Meier, M. F. (August 1971). A comparison of glacier mass balance by glaciological, hydrological and mapping methods, South Cascade Glacier, Washington. Paper presented at the meeting of Proceedings of the Snow and Ice-Symposium Neiges et Glaces, Moscow Symposium.

Thompson, D., Tootle, G., Kerr, G., Sivanpillai, R. \& Pochop, L. O. (2011). Glacier Variability in the Wind River Range, Wyoming. Journal of Hydrological Engineering, 16(10), 798-805. doi:10.1061/(ASCE)HE.1943-5584.0000384.

Turnipseed, D. P. \& Sauer, V. B. (2010). Discharge measurements at gaging stations. In Anonymous U.S. Geological Survey Techniques and Methods book 3, chap. A8. (Anonymous Trans.). (, pp. 1-106). Reston, Virginia: U.S. Geological Survey.

The Wilderness Act of 1964. Public Law 88-577 (16 U.S. C. 1131-1136) 88th Congress, Second Session September 3, 1964 (1964).

USDA. (2018). National Agricultural Imagery Program. United States Department Agriculture: Farm Service Agency: https://www.fsa.usda.gov/programs-and-services/aerialphotography/imagery-programs/naip-imagery/ [Last Accessed: 10-9-2018]

USEPA. (1983). Methods for Chemical Analysis of Water and Wastes (Report No. 600/4-79020). Washington, D.C.: United States Environmental Protection Agency: http://nepis.epa.gov/Exe/ZyPURL.cgi?Dockey=30000Q10.txt [Last Accessed: 10-9-2018]

USGS. (2018). National Water Information System: Web Interface. United States Geological Survey: https://waterdata.usgs.gov/nwis [Last Accessed: 11-9-2018]

Vandeberg, G. S. \& VanLooy, J. A. (2016). Continental Glacier meltwater contributions to late summer stream flow and water quality in the northern Wind River Range, Wyoming, USA. Environmental Earth Sciences, 75(5), 1-14. doi:10.1007/s12665-016-5295-0.

VanLooy, J. A., Forster, R. R., Barta, D. \& Turrin, J. (2013). Spatially variable surface elevation changes and estimated melt water contribution of Continental Glacier in the Wind River Range, Wyoming, USA: 1966-2011. Geocarto International, 28(2), 98-113.

doi:10.1080/10106049.2012.665500.

Williams, M.A., Wilson, A., Tshering, D., Thapa, P. \& Kayastha, R.B. (2016). Using geochemical and isotopic chemistry to evaluate glacier melt contributions to the Chamkar Chhu (river), Bhutan. Annals of Glaciology, 57(71), 339-348. doi: 10.3189/2016AoG71A068. 
Xu, J., Grumbine, R. E., Shrestha, A., Eriksson, M., Yang, X., Wang, Y. \& Wilkes, A. (2009). The melting Himalayas: Cascading effects of climate change on water, biodiversity, and livelihoods. Conservation Biology, 23(3), 520-530. doi:10.1111/j.1523-1739.2009.01237.x.

Zhang, Q., Zhang, F., Kang, S. \& Cong, Z. (2017). Melting glaciers: Hidden hazards. Science, 356(6337), 495. doi:10.1126/science.aan4118. 
Table 1.

\begin{tabular}{|l|l|l|}
\hline & $\begin{array}{l}\boldsymbol{Q} \pm \boldsymbol{\sigma} \mathbf{~ m}^{\mathbf{3}} \mathbf{~ s}^{-\mathbf{1}} \\
\text { (August 2015) }\end{array}$ & $\begin{array}{l}\text { \%Q to BLC } \\
\text { (USGS Station ID } \\
\mathbf{\# 0 6 2 2 4 0 0 )}\end{array}$ \\
\hline $\begin{array}{l}\text { Knife Point } \\
\text { Glacier (KP-2) }\end{array}$ & $0.40 \pm 0.25$ & 5.7 \\
\hline $\begin{array}{l}\text { Bull Lake Glacier } \\
\text { (BL-2) }\end{array}$ & $0.57 \pm 0.42^{*}$ & 8.1 \\
\hline $\begin{array}{l}\text { Bull Lake/Knife } \\
\text { Point (BL-3) }\end{array}$ & $0.97 \pm 0.59$ & 13.9 \\
\hline $\begin{array}{l}\text { Estimated All } \\
\text { Bull Lake Creek } \\
\text { Glaciers }\end{array}$ & $3.89 \pm 2.41$ & 55.6 \\
\hline
\end{tabular}

*Calculated as the difference between mean discharge $(Q)$ of BL-3 and KP-2; uncertainty is the average of the standard deviation of KP-2 and BL-3. 
Table 2.

\begin{tabular}{|l|l|l|l|}
\hline $\begin{array}{r}\text { Sample } \\
\text { location }\end{array}$ & $\begin{array}{c}\text { Number of } \\
\text { samples }\end{array}$ & \multicolumn{1}{|c|}{$\boldsymbol{\delta}^{\mathbf{2}} \mathbf{H}$ \%oo (s.d.) } & \multicolumn{1}{c|}{$\boldsymbol{\delta}^{\mathbf{1 8}} \mathbf{0}$ \%o (s.d.) } \\
\hline BL-2 & 2 & $-123.0(0.00)$ & $-17.15(0.07)$ \\
\hline BL-3 & 4 & $-116.5(0.58)$ & $-16.48(0.05)$ \\
\hline KP-1 & 2 & $-128.0(0.00)$ & $-17.60(0.00)$ \\
\hline KP-2 & 2 & $-120.0(0.00)$ & $-16.85(0.07)$ \\
\hline SNO-2 & 2 & $-101.5(0.71)$ & $-14.25(0.07)$ \\
\hline
\end{tabular}


Table 3.

\begin{tabular}{|l|l|}
\hline \multicolumn{1}{|c|}{$\begin{array}{c}\text { Source } \\
\text { location }\end{array}$} & $\begin{array}{l}\text { Contribution (\% } \\
\text { and s.d.) }\end{array}$ \\
\hline $\begin{array}{l}\text { Glacial } \\
\text { meltwater } \\
\text { BL-2 }\end{array}$ & $75.72 \pm 6.4$ \\
KP-2 & $84.84 \pm 6.4$ \\
\hline $\begin{array}{l}\text { Total glacier } \\
\text { meltwater } \\
\text { (mean) }\end{array}$ & $80.02 \pm 6.4$ \\
\hline $\begin{array}{l}\text { Snow } \\
\text { meltwater } \\
\text { SNO-2 }\end{array}$ & $19.97 \pm 6.4$ \\
\hline
\end{tabular}


Table 4.

\begin{tabular}{|c|c|c|c|c|c|}
\hline Parameter & $\begin{array}{c}\text { Bull Lake } \\
\text { Glacier } \\
\text { meltwater } \\
(\text { BL-2) }\end{array}$ & $\begin{array}{l}\text { Knife Point } \\
\text { Glacier } \\
\text { surface } \\
\text { meltwater } \\
(\text { KP-1) } \\
\end{array}$ & $\begin{array}{c}\text { Knife Point } \\
\text { Glacier } \\
\text { meltwater } \\
\text { (KP-2) }\end{array}$ & $\begin{array}{c}\text { Bull Lake } \\
\text { Creek } \\
\left(\mathrm{BL}-3^{\mathrm{a}}\right)\end{array}$ & $\begin{array}{c}\text { Snow } \\
\text { sample } \\
\text { (SNO-2) }\end{array}$ \\
\hline \multicolumn{6}{|l|}{ Field } \\
\hline $\mathrm{pH}$ & $---b$ & 6.34 & $6.76 \pm 0.20$ & $7.05 \pm 0.12$ & -- \\
\hline Temp $\left({ }^{\circ} \mathrm{C}\right)$ & -- & $0.20 \pm 0.10$ & $3.29 \pm 1.05$ & $3.13 \pm 0.91$ & -- \\
\hline $\begin{array}{l}\text { Specific cond. } \\
\qquad\left(\mu \mathrm{S} \mathrm{cm}^{-1)}\right.\end{array}$ & -- & $2.16 \pm 0.41$ & $7.23 \pm 1.97$ & $10.9 \pm 3.50$ & -- \\
\hline \multicolumn{6}{|l|}{ Nutrients } \\
\hline $\begin{array}{c}\mathrm{NO}_{3}-\mathrm{NO}_{2} \\
\left(\mathrm{mg} \mathrm{l}^{-1}\right)\end{array}$ & 0.11 & 0.02 & 0.18 & $0.28-0.30$ & 0.07 \\
\hline $\mathrm{TKN}\left(\mathrm{mg} \mathrm{l}^{-1}\right)$ & $<0.5$ & $<0.5$ & $<0.5$ & $<0.5$ & 8.2 \\
\hline $\mathrm{N}$ tot. $\left(\mathrm{mg} \mathrm{l}^{-1}\right)$ & $<0.5$ & $<0.5$ & $<0.5$ & $<0.5$ & 8.3 \\
\hline$P$ tot. $\left(\mathrm{mg} \mathrm{l}^{-1}\right)$ & 0.198 & 0.045 & 0.063 & $0.026-0.029$ & 6.75 \\
\hline \multicolumn{6}{|l|}{ Major Ions } \\
\hline $\mathrm{Ca}\left(\mathrm{mg} \mathrm{l}^{-1}\right)$ & 2 & $<1$ & 1 & 2 & 16 \\
\hline $\operatorname{Mg}\left(\mathrm{mg} \mathrm{l}^{-1}\right)$ & 2 & $<1$ & 1 & $<1$ & 28 \\
\hline $\mathrm{K}\left(\mathrm{mg} \mathrm{l}^{-1}\right)$ & 2 & $<1$ & 1 & $<1$ & 19 \\
\hline $\mathrm{Si}\left(\mathrm{mg} \mathrm{l}^{-1}\right)$ & 8.7 & 1.7 & 4.3 & 2.8 & 68.8 \\
\hline $\mathrm{Na}\left(\mathrm{mg} \mathrm{l}^{-1}\right)$ & $<1$ & $<1$ & $<1$ & $<1$ & 3 \\
\hline $\mathrm{SO}_{4}\left(\mathrm{mg} \mathrm{l}^{-1}\right)$ & $<1$ & $<1$ & $<1$ & $<1$ & $<1$ \\
\hline \multicolumn{6}{|l|}{$\begin{array}{c}\text { Total } \\
\text { recoverable } \\
\text { elements }\end{array}$} \\
\hline $\mathrm{Al}\left(\mathrm{mg} \mathrm{l}^{-1}\right)$ & 4.39 & 1.00 & 2.27 & $1.16-1.22$ & 43.5 \\
\hline As $\left(\mathrm{mg} \mathrm{l}^{-1}\right)$ & $<0.001$ & $<0.001$ & $<0.001$ & $<0.001$ & 0.008 \\
\hline $\mathrm{Be}\left(\mathrm{mg} \mathrm{l}^{-1}\right)$ & $<0.001$ & $<0.001$ & $<0.001$ & $<0.001$ & 0.002 \\
\hline $\mathrm{B}\left(\mathrm{mg} \mathrm{l}^{-1}\right)$ & $<0.05$ & $<0.05$ & $<0.05$ & $<0.05$ & $<0.05$ \\
\hline $\mathrm{Cr}\left(\mathrm{mg} \mathrm{l}^{-1}\right)$ & $<0.005$ & $<0.005$ & $<0.005$ & $<0.005$ & 0.045 \\
\hline $\mathrm{Cu}\left(\mathrm{mg} \mathrm{l}^{-1}\right)$ & 0.006 & $<0.005$ & $<0.005$ & $<0.005$ & 0.105 \\
\hline $\mathrm{Fe}\left(\mathrm{mg} \mathrm{l}^{-1}\right)$ & 4.70 & 1.05 & 2.21 & $0.85-0.86$ & 60.4 \\
\hline $\mathrm{Pb}\left(\mathrm{mg} \mathrm{l}^{-1}\right)$ & 0.007 & 0.002 & 0.002 & $<0.001-0.001$ & 0.075 \\
\hline $\operatorname{Mn}\left(\mathrm{mg} \mathrm{l}^{-1}\right)$ & 0.089 & 0.020 & 0.041 & $0.016-0.017$ & 1.30 \\
\hline $\operatorname{Hg}\left(\mathrm{mg} \mathrm{l}^{-1}\right)$ & $<0.0001$ & $<0.0001$ & $<0.0001$ & $<0.0001$ & 0.0002 \\
\hline Mo (mg l-1) & $<0.001$ & $<0.001$ & $<0.001$ & $<0.001$ & $<0.001$ \\
\hline Se $\left(\mathrm{mg} \mathrm{l}^{-1}\right)$ & $<0.001$ & $<0.001$ & $<0.001$ & $<0.001$ & $<0.001$ \\
\hline $\operatorname{Ag}\left(\mathrm{mg} \mathrm{l}^{-1}\right)$ & $<0.001$ & $<0.001$ & $<0.001$ & $<0.001$ & $<0.001$ \\
\hline $\mathrm{Sr}\left(\mathrm{mg} \mathrm{l}^{-1}\right)$ & 0.01 & $<0.01$ & $<0.01$ & $<0.01$ & 0.09 \\
\hline $\mathrm{Tl}\left(\mathrm{mg} \mathrm{l}^{-1}\right)$ & $<0.0005$ & $<0.0005$ & $<0.0005$ & $<0.0005$ & 0.0012 \\
\hline $\mathrm{Ti}\left(\mathrm{mg} \mathrm{l}^{-1}\right)$ & 0.280 & 0.054 & 0.137 & $0.052-0.055$ & 2.66 \\
\hline $\mathrm{V}\left(\mathrm{mg} \mathrm{l}^{-1}\right)$ & $<0.01$ & $<0.01$ & $<0.01$ & $<0.01$ & 0.10 \\
\hline $\mathrm{Zn}\left(\mathrm{mg} \mathrm{l}^{-1}\right)$ & 0.02 & $<0.01$ & $<0.01$ & $<0.01$ & 0.25 \\
\hline
\end{tabular}

${ }^{a}$ mean or range (when only two samples) includes field duplicate of BL-3 for quality assurance and control

${ }^{b}$ not available 


\section{Table Captions}

Table 1. Mean discharge $(Q)$ and standard deviation $(\sigma)$ measured from Knife Point Glacier (KP2), Bull Lake Glacier (BL-2), below the Knife Point/Bull Lake Glacier outlet stream confluence (BL-3), and an estimate for all Bull Lake Creek Glaciers, and percent discharge contribution to Bull Lake Creek (BLC) above Bull Lake Reservoir (at USGS station \#06224000).

Table 2. Mean and standard deviation (s.d.) results of stable isotope analysis of $\delta^{2} \mathrm{H}$ and $\delta^{18} \mathrm{O}$ in glacial meltwater (BL-2, KP-2), supraglacial meltwater (KP-1), stream water (BL-3) and snow (SNO-2).

Table 3. Contributions of water sources to Bull Lake Creek (BL-3) flow based on isotope data and two part mixing model.

Table 4. Field and analytical data (mean and standard deviation) for meltwater, streams and snow in Bull Lake drainage, Wyoming, 2015. 


\section{Figure Captions}

Figure 1. Study area of Bull Lake Creek watershed. Inset at top center shows location of Torrey Creek watershed where Continental Glacier is located, along with SNOTEL stations (black triangles; GP: Gunsight Pass, EP: Elkhart Park, and CS: Cold Spring), and USGS streamflow gaging stations (black squares; BLC: Bull Lake Creek above Bull Lake Reservoir, DC: Dinwoody Creek, PC: Pine Creek, and GR: Green River). Inset at lower right shows locations of the five largest glaciers in the Bull Lake Creek watershed. Glacier outlines depict September 2015 boundaries. Background shaded relief and watershed boundaries generated from Shuttle Radar Topographic Mission (SRTM) DEM.

Figure 2. Locations of stream flow measurements, isotope samples, and temperature data loggers at the August 2015 field site on and around Knife Point and Bull Lake Glaciers. Background is NAIP imagery from September 2015.

Figure 3. Hydrograph of measured and gaged discharge $(Q)$ at KP-2 (measured discharge represented by open circles, and gaged discharge represented by dotted line) and BL-3 (measured discharge represented by open triangles, and gaged discharge represented by dashed line) field sites, along with temperature ( $T$ ) at CT-1 (light gray line), GT-1 (dark gray line), and GT-2 (black line) field sites during August 2015.

Figure 4. Glacier area $\left(A \mathrm{~km}^{2}\right)$ versus average glacier discharge $\left(\bar{Q} \mathrm{~m}^{3} \mathrm{~s}^{-1}\right)$ for Knife Point (KP2), Bull Lake (BL-2), and Continental Glaciers (black circles). Trend line represented by the dashed line with the equation, $\mathrm{R}^{2}$, and $\mathrm{p}$-value above. Open circles represent the estimated glacial discharge $\left(\bar{Q} \mathrm{~m}^{3} \mathrm{~s}^{-1}\right)$ by area for all glaciers without 2015 field discharge measurements in the Bull Lake Creek watershed.

Figure 5. Isotopes and local meteoric line (WY LML from Benjamin et al. 2007).

Figure 6. Comparison of nutrient loading rates from glacial meltwater in the Wind River Range, WY from this study and Vandeberg and VanLooy (2016). CG-1 is Continental Glacier meltwater, TCR-1 is Torrey Creek, and WR-1 is the Wind River near Dubois, WY from August 2014. 